\title{
Integrated Nutrient Management: An Effective Approach for Sustainable Agriculture in Chhattisgarh: A Review
}

\author{
S.P. Singh*, Chanchala Rani Patel and K.K. Paikra \\ Krishi Vigyan Kendra, Raigarh-496001 (C.G.), \\ Indira Gandhi Krishi Viswavidyalaya, Raipur (C.G.), India \\ *Corresponding author
}

\begin{abstract}
A B S T R A C T
Integrated Nutrient Management approach to the management of plant nutrients for maintaining and enhancing soil, Soil fertility maintenance requires a balanced application of inorganic and organic nutrient sources. Sustainable agricultural productivity might be achieved through wise use of integrated nutrient management. Integrated use of the organic and inorganic source of plant nutrients on growth and yield attributes is very crucial for the assurance of food security. The integrated plant nutrient supply/management is an important approach for maintenance or adjustment of soil fertility and plant nutrient supply to an optimum level for sustainable crop productivity through optimization of benefit from all possible sources of plant nutrients in an integrated manner which includes; Maintain or enhance soil productivity through a balanced use of fertilizers combined with organic and biological sources of plant nutrients and also to reduce inorganic (fertilizer) input cost. Organic sources such as FYM, bio compost, vermicompost, NADEP compost, green manures, crop residues and industrial wastes have been used in various cropping systems. Soil as a source of nutrients must be protected from all kinds of external factors, especially from the addition of fertilizers in excessive rates. Any degradation in the quality of soil can significantly produce many undesirable changes in the environment and also reduces the overall crop yield. The amount and availability of nutrients in organic materials vary widely, which interprets the value of nutrients supplied.
\end{abstract}

\section{Keywords}

Integrated nutrient management, Organic and inorganic fertilizer, Bio-fertilizer, sustainability

Article Info

Accepted:

15 April 2020 Available Online: 10 May 2020

\section{Introduction}

Integrated nutrient management is judicious use of organic and inorganic sources of nutrients for sustaining and maintaining soil productivity. Imbalance fertilization has a key role to play in obtaining low productivity, so to achieve optimum crop production management of nutrients through judicious application of organic sources, bio-fertilizers
and
micro-nutrients
are
required.
Furthermore, fertilizer management is one of the most important factors that influence the growth and yield of maize crop (Ghaffari et al., 2011). The use of chemical fertilizers in conjunction with organic manures like compost, farmyard manure, vermicompost, green manures, fortified micro-nutrients fertilizers, bio-fertilizers (e.g. phosphate solubilizing bacteria, Azospirillum, 
Azotobacter, Rhizobium, and Potash mobilizing bio-fertilizers) that can supplement a part of NPK fertilizers. Therefore, there is a need to improve nutrient supply system in terms of integrated nutrient management involving the use of chemical fertilizers in conjunction with organic manures coupled with input through biological processes. However, the role of major nutrients on crop physiology and the effect of these nutrients on growth, quality, yield and yield components of cereal crops. Above all, the role of balanced fertilizer is the application of essential plant nutrients in light proportion and in optimum quantity for a specific soil crop condition in alleviating the yield, quality and its attributes (Chondie, 2015).

Appropriate and conjunctive use of application of suitable nutrients through organic and inorganic solely or in combination can provide the solutions to the problems such as an increase in the price of inorganic fertilizers and deterioration effect of soil fertility and productivity. Hence, the judicious application of these combinations can sustain soil fertility and productivity (Sindhi et al., 2018). Integrated use of nutrient is a very essential approach, which not only sustains high crop production over the years but also improves soil health and ensures a safer environment. Biofertilizers can prove to be an effective low-cost technology for the farmers. Thus, there is a need to improve the nutrient supply systems in terms of integrated nutrient management involving the use of fertilizers in conjunction with organic manures and fertilizers (Singh et al., 2018). Integrated nutrient management is the only possible approach in enhancing soil productivity through a balanced use of mineral fertilizers combined with organic and biological sources of plant nutrients. It plays a vital role in improving the stock of plant nutrients in the soil by increasing the efficiency of plant nutrients, thus limiting losses to the environment. It optimizes the function of the soil biosphere and ultimately sustaining the physical, chemical and biological functioning of soil etc. (Joy et al., 2018). Integrated nutrient management is the balanced and judicious uses of manures and chemical fertilizers are known to have a promising effect in arresting the decline in productivity through correction of marginal nutrient deficiencies and their positive influence on the physical and biological soil properties. This system can bring about equilibrium between degenerative and restorative activities in the soil environment (Yadav and Kumar, 2009).

Micronutrients have a promising effect on the growth and development of crop plants. Use of micronutrients improves the quality and quantity of agricultural produce. Approximately $70-80 \%$ of the nitrogen, 60$85 \%$ of the phosphorus and $80-90 \%$ of the potassium in feeds is excreted in the manure. He further added that manure contains all the plant nutrients needed for crop growth including trace elements. The availability or efficiency of manure utilization by a crop is determined by the method of application, time to incorporation and the rate of manure decomposition by microorganisms in the soil. A long term imbalanced use of fertilizers like NPK and some micronutrients is adversely affecting the sustainability of agricultural production eventually causing environmental pollution. Soils which receive plant nutrients only through chemical fertilizers are showing declining productivity despite being supplied with sufficient nutrients. This can be attributed to the appearance of deficiency in secondary and micronutrients. The physical condition of the soil is deteriorated as a result of long-term use of chemical fertilizers. It also aggravates the problem of poor fertilizer nutrient use efficiency (NUE) (Joy et al., 2018). 


\section{Effect on growth and yield attributes}

Organic and inorganic sources of plant nutrients play a significant role in growth parameters and yield attributes. The maximum plant height and the number of tillers per plant were observed with (120: 60: 40: 25 NPK Zn kg ha ${ }^{-1}, 10 \mathrm{t} \mathrm{ha}^{-1}$ FYM) which was $86.43 \mathrm{~cm}$ and 7.33 , respectively (Sangma et al., 2017). The growth parameter (plant height) and crop dry matter were significantly affected with $100 \%$ NPK + FYM $10 \mathrm{t} \mathrm{ha}^{-1}$ (Arvind et al., 2006). The results are following those of Singh et al., (2008). They reported that growth attributes (plant height, number of tillers and grains per spike) were significantly higher with FYM @ $7.5 \mathrm{t} \mathrm{ha}^{-1}$ $+50 \% \mathrm{RDF}+$ biofertilizers. The increase in plant height and number of effective tillers by INM treatments might be due to the addition of nitrogen as well as other nutrients and growth-promoting substances through organic manure. Maximum dry matter accumulation, plant height, number of leaves per plant, leaf area index, cob girth, cob length, cobs per plant, green cob weight, number of grains per cob, 100 seed weight, green cob yield, green fodder yield, grain yield and biological yield were obtained with the application of $100 \%$ RDF (120: 60: 00, NPK kg ha-1) with $10 \mathrm{t} \mathrm{ha}^{-1}$ FYM. Similarly, the above growth and yield attributes produced by the application of different combinations of RDF with FYM were found to be significantly higher than the other treatments (Khadtare et al., 2006, Tetarwal et a., 2011, Shilpashree et a., 2012 and Kannan et al., 2013). Application of 100 $\mathrm{kg} \mathrm{N}$ ha $^{-1}$ along with $7.5 \mathrm{t}$ FYM ha ${ }^{-1}$ significantly influenced the plant height, leaf area index and the number of days to maturity, yield attributes such as the diameter of cob, weight of cobs per plant, grain and straw yields of maize (Verma et al., 2012). Dry matter accumulation, the number of effective tillers, grains spike ${ }^{-1}$ and the test weight increased with the integrated use of fertilizers with vermicompost and phosphate solubilizing bacteria. Addition of vermicompost with or without PSB together with different fertilizer levels produced significantly higher grain and biological yields than the application of fertilizers alone. Maximum grain yield and biological yield were obtained with the application of $100 \%$ RDF+ vermicompost @ $1 \mathrm{tha}^{-1}+\mathrm{PSB}$ and 75 $\%$ RDF+ vermicompost @ 1 t ha- ${ }^{1}+$ PSB (4.89 $\mathrm{t} \mathrm{ha}^{-1}$ ). Similarly, the number of effective tillers, grains spike ${ }^{-1}$ and test weight produced by the application $100 \% \mathrm{RDF}+$ vermicompost @ $1 \mathrm{t} \mathrm{ha}^{-1}+$ PSB and $75 \%$ $\mathrm{RDF}+$ vermicompost @ $1 \mathrm{t} \mathrm{ha}^{-1}+\mathrm{PSB}$ were found to be significantly higher than the other treatments (Devi et al., 2011). Application of PSB along with organic manures or with other combinations significantly increased the number of tillers $\mathrm{m}^{-2}$. These results are in line with the findings of Kumar et al., (1999) who reported a significant increase in the number of plants per meter row by inoculation of Azotobacter chrococcum (Afzal et al., 2005). Significant effects observed by INM in tillers and test weight of wheat. Among the different treatments, (75\% RDF + 10 t FYM ha ${ }^{-1}$ ) registered maximum value for plant height $(78.00 \mathrm{~cm})$, number of effective tillers $(82.77)$

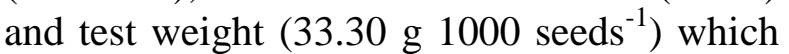
was significantly more than RDF. The increase in the yield attributing characters by INM treatments might be due to the addition of nitrogen as well as other nutrients and growth-promoting substances through organic manure (Tej Alben et al., 2017). Injudicious fertilization has a key role to play of major nutrients on crop physiology and the effect of these nutrients on growth, quality, yield, and yield components of cereal crops. The plant height, dry matter accumulation, leaf area index, and higher grain yield were significantly increased with the application of $100 \%$ RDF (135: 62: 50, NPK, $\mathrm{kg} \mathrm{ha}^{-1}$ ) with $5.0 \mathrm{t} \mathrm{ha}^{-1}$ vermicompost (Louraduraj, 2006). The growth and yield attributes viz., plant 
height, leaf area index, number of cobs plant 1, dry matter production, 1000 grain weight, grain and straw yields were significantly influenced with $100 \% \operatorname{RDF}$ (120: 60: 40, NPK, $\mathrm{kg} \mathrm{ha}^{-1}$ ) with $5.0 \mathrm{t} \mathrm{ha}^{-1}$ vermicompost (Pawar and Patil, 2007, Joshi et al., 2013 and Pandey and Avasthi, 2014). Shinde et al., (2014) and Maske et al., (2015) reported that the application of $100 \%$ RDF (120: 60: 40 NPK kg ha ${ }^{-1}$ ) with $10 \mathrm{t} \mathrm{ha}^{-1}$ FYM gave higher grain and straw yields of maize. The yield attributes (number of ears, ear weight, 1000 seed weight) were significantly influenced with $5 \mathrm{tha}^{-1}$ crop residue $+5 \mathrm{tha}^{-1} \mathrm{FYM}+5$ $\mathrm{kg} \mathrm{ha}^{-1} \mathrm{Zn}$ treatments (Totawat et al., 2001 and Gawai and Pawar, 2006). The 100\% RDF $+5 \mathrm{t} \mathrm{ha}^{-1}$ FYM significantly gave higher wheat yield (Shivkumar and Ahlawat, 2008). Parihar et al., (2010) postulated that the FYM improving soil physical, chemical, and biological properties and had a synergistic relationship with $\mathrm{N}, \mathrm{P}$, thereby helping in mineralization of applied $\mathrm{N}$ and $\mathrm{P}$ helped in increasing the growth and meanwhile grain yield. From the above results, it can be concluded that supplementation of $75 \%$ RDF along with $10 \mathrm{t}$ FYM ha ${ }^{-1}$ significantly improved the plant height and effective tillers which reflected in increasing grain and straw yield of wheat. The growth parameters viz., plant height, leaf area index, grain and straw yields of hybrid maize were significantly influenced with the application of $50 \% \mathrm{RDF}$ through poultry manure $+50 \%$ RDF through inorganic fertilizers followed by $50 \% \mathrm{RDF}$ through vermicompost $+50 \%$ RDF through inorganic fertilizers (Nagavani and Subbian, 2014). Organic and inorganic sources of nutrients combinations with the application of $25 \% \operatorname{RDF}$ (30: 15: 15, NPK, kg ha ${ }^{-1}$ ), biofertilizers (Azotobacter+ PSB), green manuring of sunhemp and compost resulted in significantly taller plants, maximum total plant dry matter accumulation and to increase the productivity of hybrid maize (Kalhapure et al., 2013). Iqbal et al., (2014) reported that significantly highest plant height and the number of leaves per plant observed under application of $75 \% \mathrm{~N}$ from urea $+25 \% \mathrm{~N}$ from poultry manure which was at par with $100 \% \mathrm{~N}$ from urea in maize. Application of 150:75:00 NPK kg ha ${ }^{-1}+$ FYM @ $5 \mathrm{t} \mathrm{ha}^{-1}+$ Azotobacter+ PSB + Sulphur @ $40 \mathrm{~kg} \mathrm{ha}^{-1} \mathrm{ha}$ (gypsum) produced a significant effect. The per cent increase in the number of spikes per metre row length, length of spike and number of grains per spike were $34.35 \%, 28 \%$ and $31 \%$, respectively over the RDF 120: 60: 00 NPK kg ha ${ }^{-1}$ (Desai et al., 2015). Similar results were obtained by Singh et al., (2008), Pandey et al., (2009), Mubrak and Singh (2011) and Ali et al., (2012). The magnitude of increase under the treatment [150: 75: 00 NPK kg ha ${ }^{-1}+$ FYM @ $5 \mathrm{t} \mathrm{ha}^{-1}+$ Azotobacter+ PSB + Sulphur @ $40 \mathrm{~kg} \mathrm{ha}^{-1}$ (gypsum)] was $31.61 \%$ and $33.80 \%$, respectively with respect to grain and straw yield as compared to the treatment 120: 60: 00 NPK kg ha ${ }^{-1}$. This is might be due to combined effect of organic manure (FYM), biofertilizers and chemical fertilizers with sulphur in balanced proportion played a very vital role in decomposition and easy release of different nutrients and their uptake by the crop which led to higher dry matter accumulation and its translocation in different plant parts of growth and yield parameters, which in turn resulted into higher yield (Desai et al., 2015). These results are following those of Pandey et al., 2009 and Sepat et al., 2010. The highest mean number of grains per spike (61.42), 1000 grain weight (44.76 g), grain yield (50.93 q ha ${ }^{-1}$ ) and straw yield (126.76 q $\mathrm{ha}^{-1}$ ) were recorded in the treatment in which $100 \% \mathrm{~N}, \mathrm{P}$ and $\mathrm{K}$ was clubbed with FYM and $\mathrm{Zn}$. The lowest mean number of grains per spike (50.74), 1000 grain weight (42.66 $\mathrm{g}$ ), grain yield (40.51 q ha $\left.{ }^{-1}\right)$ and straw yield $\left(82.90 \mathrm{q} \mathrm{ha}^{-1}\right)$ were recorded with control (Sangma et al., 2017). Choudhary et al., (2003) also reported that the significant effect of INM on yield attributes. Furthermore, 
fertilizer management is one of the most important factors that influence the growth and yield of maize crop (Ghaffari, et al., 2011). Singh and Tomar (1991) reported that application of Farmyard Manure helps to increase the dry matter production, yield and nutrient uptake by wheat. The soil incorporation of mustard/ taramira + FYM and FYM at $10 \mathrm{t} \mathrm{ha}^{-1}$ significantly increased grain yield of wheat (Regar et al., 2005). Application of FYM @ 10 and $2010 \mathrm{t} \mathrm{ha}^{-1}$ increased the grain yield and total N P and K uptake in wheat crop (Singh and Agrawal, 2005). FYM application (10 $\left.\mathrm{tha}^{-1}\right)$ resulted in a $21.5 \%$ increase in grain and straw yield. The response of FYM measured as $\mathrm{kg}$ grain tonne $^{-1}$ was highest in wheat (Mahapatra et al., 2007). The combination of organic and inorganic $\mathrm{N}$ sources resulted in comparable rice yield to the application of inorganic nitrogen alone (Rao et al., 1996). The greatest grain yield of wheat was found with inoculation of bacteria (Saad and Hamimad, 1998). Application of phosphate solubilizing micro-organism (PSM) in combination with phosphorus fertilizer and organic manure significantly improved grain and biological yield of wheat (Afzal et al., 2005). The grain and straw yield increased significantly due to various treatments over control. Grain yield further increased significantly when 150;60: 60 NPK combined single either with FYM, sulphur or boron over sole use of 150; 60: 60 NPK. Reducing the dose of NPK of the recommended dose (150; 60: 60 NPK) by $25 \%$ and combining with Sulphur + boron + FYM significantly increased grain yield over sole use of 150; 60: 60 NPK and also significantly increased the straw yield over sole use of 150; 60: 60 NPK. Highest grain $45.26 \mathrm{q} \mathrm{ha}^{-1}$ and straw yield $56.94 \mathrm{q} \mathrm{ha}^{-1}$ were noted with $(75 \% \mathrm{NPK}+\mathrm{S}+\mathrm{B}+10 \mathrm{t}$ FYM). The yield increase may be due to the addition of individual FYM, sulphur or boron with $100 \%$ NPK (150:60:60), significantly influenced plant growth compared to sole NPK source.
Increase grain \& straw yield due to integrated use of FYM, sulphur and boron with $75 \%$ NPK may be due to synergistic effect of all inputs when combined with $75 \%$ NPK (Reena et al., 2017). Similar results also reported by Reddy et al., 2009 and Singh and Kumar, (2010). Above all, the role of balanced fertilizer is the application of essential plant nutrients in light proportion and in optimum quantity for a specific soil crop condition in alleviating the yield, quality and its attributes (Chondie, 2015).

\section{Effect on nutrient composition, nutrient uptake and soil status}

Nutrient management plays a vital role in enhancing soil productivity through judicious balanced use of inorganic fertilizers combined with organic and biological sources of plant nutrients. It is improving the plant nutrients status in soil by increasing the efficiency of plant nutrients, thus limiting losses to the environment. It optimizes the function of the soil biosphere and ultimately sustaining the physical, chemical and biological functioning of soil etc. (Joy et al., 2018). Application of vermicompost + PSB along with fertilizer levels significantly increased the available nitrogen, phosphorus and potash status of the soil. Available NPK of soil after the harvest of wheat was found to be maximum with the application of $100 \%$ RDF + vermicompost @ $1 \mathrm{t} \mathrm{ha}{ }^{-1}+$ PSB and $75 \% \mathrm{RDF}+$ vermicompost @ $1 \mathrm{t} \mathrm{ha}^{-1}+$ PSB and the lowest from control (Devi et al., 2011). Pandey et al., (2009) also reported that addition of organic manure (10 $\left.\mathrm{t} \mathrm{ha}^{-1} \mathrm{FYM}\right)$ with fertilizer levels significantly increased the nutrient uptake by wheat, improved the organic carbon content $\mathrm{N}, \mathrm{P}$ and $\mathrm{K}$ status as compared to chemical fertilizer alone. The increase in nitrogen, phosphorus and potash status of the soil is due to the application of vermicompost and PSB which enhances the activity of some microbial populations. Use of 
green manure crop (Erythrina bruice) either its biomass alone or in combination with mineral fertilizer is found to increase the yield and yield components of bread wheat. Erythrina bruice is a nitrogen-fixing plant, which fixes the nitrogen through its leaves; this is a fast-growing nutrient-rich plant particularly high with nutrient contents on NPK (Haile, 2012). Integrated use of chemical and organic fertilizer has proved to be highly beneficial for sustainable crop production. Several researchers have demonstrated the beneficial effect of combined use of chemical and organic fertilizers to mitigate the deficiency of many secondary and micronutrients in fields that continuously received only $\mathrm{N}, \mathrm{P}$ and $\mathrm{K}$ fertilizers (Chand et al., 2006). Integrated nutrient-management program in which both organic manure and inorganic fertilizer are used has been emphasized as a rational strategy in improving yield (Wakena et al., 2002; Abay and Tesfaye, 2012; Dejene et al., 2012). It is commonly believed that the combination of organic and inorganic fertilizer will increase synchrony, enhancing the efficiency of the fertilizers, and reduce losses by converting inorganic nitrogen $(\mathrm{N})$ into organic forms but also reducing environmental problems that may arise from their use. Thus, the study reflects those integrated use of chemical fertilizers, organic manures including green manure and recycling of crop residues, assume the greater significance of improving the efficiency of chemical fertilizers in the soil.

Appropriate and conjunctive use of application of suitable nutrients through organic and inorganic solely or in combination can provide the solutions to the problems such as increase in the price of inorganic fertilizers and deterioration effect of soil fertility and productivity. Hence, judicious application of these combinations can sustain the soil fertility and productivity
(Sindhi et al., 2018). Integrated use of nutrient is very essential approach, which not only sustains high crop production over the years but also improves soil health and ensures safer environment. An application of $120 \mathrm{~kg} \mathrm{~N} \mathrm{ha}^{-1}+1.5 \mathrm{t} \mathrm{ha}^{-1}$ vermicompost resulted in significantly higher nutrient content and uptake compared with $80 \mathrm{~kg} \mathrm{~N}$ $\mathrm{ha}^{-1}+1.5 \mathrm{t} \mathrm{ha}^{-1}$ vermicompost in maize (Meena et al., 2007). Nutrients combinations with application of bio compost @ $5 \mathrm{t} \mathrm{ha}^{-1}$ with $75 \% \mathrm{~N}$ and $\mathrm{P}$ through fertilizer (100\% RDF 120: 60: 60 NPK kg ha ${ }^{-1}$ ) recorded higher available organic carbon and $\mathrm{N}$ in soil after crop harvest (Tripathi et al., 2007). The results revealed that significantly higher values of organic carbon, available $\mathrm{N}, \mathrm{P}_{2} \mathrm{O}_{5}$ and $\mathrm{K}_{2} \mathrm{O}$ content in soil were recorded with application of $25 \%$ RDF (30:15:15 NPK kg $\left.\mathrm{ha}^{-1}\right)+$ biofertilizers (Azotobacter + PSB) + green manuring with sun hemp + compost (Kalhapure et al., 2013). Organic carbon content, $\mathrm{N}$ and $\mathrm{P}$ status of soil improved with application of vermicompost @ $5 \mathrm{t} \mathrm{ha}^{-1}$ with $100 \%$ RDF (90: $40 \mathrm{NP} \mathrm{kg} \mathrm{ha}^{-1}$ (Singh and Nepalia, 2009). Maximum NPK uptake and available $\mathrm{N}$ and $\mathrm{P}$ status to the tune of 1.28 and $14.89 \%$, were recorded with application of $100 \%$ RDF (40: 15: 00 NPK kg ha') + 10 $\mathrm{t} \mathrm{ha}^{-1}$ (Tetarwal et al., 2011). Singh et al., (2012) reported that the application of FYM (a) $10 \mathrm{t} \mathrm{ha}^{-1}$ along with $100 \%$ RDF (120:26.21:33.2 NPK $\mathrm{kg} \mathrm{ha}{ }^{-1}$ ) recorded significantly higher uptake of nitrogen and phosphorus by grain, and straw. Jabbar et al., (2008) also reported that rhe animal manures are an excellent source of plant nutrients. Application of organic amendments improves soil physical fertility (Biswas and Khosla, 1971) and using them in conjunction with organic fertilizers augments the beneficial effects. Soil organic matter imparts desirable physical environments to soils by favourably affected soil structure expressed through soil porosity, aggregation, bulk density and soil water storage (Benbi et al., 1998; Benbi and 
Nieder, 2003). FYM is applied to the soil mainly as a source of plant nutrients. Animal manure supplies all the macronutrients as well as micronutrients necessary for plant growth, hence it acts as a diverse fertilizer. Its fertilizing effect on crops can be compared to that of mineral fertilizers. Therefore, application of farmyard manure is synergistic to mineral fertilizers for various nutrients. This illustrates that nutrients from farmyard manure can be substituted for mineral fertilizers and this also improves soil environment. The porosity, CEC, organic carbon, available $\mathrm{N}, \mathrm{P}_{2} \mathrm{O}_{5}$ and $\mathrm{Zn}$ in soil recorded highest with the application of RDF (120:60:40 NPK kg ha ${ }^{-1}$ ) + FYM $10 \mathrm{t} \mathrm{ha}^{-1}$ (Pandey and Avasthi, 2014). Several experiments revealed that $\mathrm{N}$ availability was $40 \%$ for manure and $15 \%$ for compost in the first year and was $18 \%$ for manure and $8 \%$ for compost in the second year after application. Similar results showed that the combination of compost with chemical fertilizer further enhanced the biomass and grain yield of crops (Sarwar et al., 2007; Sarwar et al., 2008). Singh, et al., (2007) have shown that use of inorganic fertilizers in combination with FYM / green manure (GM) /crop residue (CR) plays an important role in improving the damaged soil structure by reducing bulk density and increasing infiltration rate and the mean weight diameter of the aggregates. Organic carbon content registered an increase varying from 28.6 to $35.7 \%$ due to continuous application of FYM, rice straw, or green karanj leaf. Besides, there is plenty evidence that application of organic fertilizer also enhances the effectiveness of commercial fertilizer through favorable soil microbial activity and augmentation of organic soil colloids (humus) that possess large nutrient retaining surface area (Manna et al., 2005). An average rate of application of organic amendments is still a very small fraction (about $100 \mathrm{~kg}$ per each small farmer per year) as compared to the total requirement of the product. As a results of land degradation problems (soil erosion, removal of crop residue for animal feed and fuel and burning of animal dung), soil with organic matter content below $2 \%$ (even below $1 \%$ in many areas) is wide spread in the country. The country in general is rich in live stock and lot of biomass that can be used as compost these integrated fertility management would help to change the existing situation. Bajpai et al., (2006) addition of organic nutrient source might have created environment conducive for formation of humic acid, stimulated the activity of soil microorganism resulted in an increase in the organic carbon content of the soil. Integrated nutrient management is balanced and judicious use of manures and chemical fertilizers is known to have a promising effect in arresting the decline in productivity through correction of marginal nutrient deficiencies and their positive influence on the physical and biological soil properties. This system can bring about equilibrium between degenerative and restorative activities in the soil environment (Yadav and Kumar, 2009). Micronutrients have a promising effect on the growth and development of the crop plants. Use of micronutrients improves the quantity of the agricultural produce. Rafique and Rashid, (2006) reported that $\mathrm{Zn}$ requirement for wheat is low (i.e., $2.0 \mathrm{~kg} \mathrm{Zn} \mathrm{ha}{ }^{-1}$ ) and $\mathrm{Zn}$ use enhances wheat productivity in a highly cost effective manner.

In conclusion, the integrated use of chemical fertilizers and organic manures including green manure and biological sources of plant nutrients, assume greater significance of improving efficiency of chemical fertilizers in soils by increasing the efficiency of plant nutrient. Soil as a source of nutrients, must be protected from all kinds of external factors, especially from the addition of fertilizers in excessive price. Integrated ways of nutrient 
management is judicious approach for maintaining the soil fertility, soil health and sustaining the environment. Any degradation in the quality of soil can significantly produce many undesirable changes in the environment and also reduces the overall crop yield. The amount and availability of nutrients in organic materials vary widely, which makes interpretation of the value of nutrients supplied.

\section{References}

Abay, A. and Tesfaye, D. (2012). Combined Application of Organic and Inorganic Fertilizers to Increase Yield of Barley and Improve Soil Properties at Fereze. Innovative Systems Design and Engineering, 3(1): 201.

Afzal, A., Ashraf, M., Saeed, A.A, and Farooq, M. (2005). Effect of phosphate solubilizing microorganisms on phosphorus uptake, yield and yield traits of wheat (Triticumaestivum L.) in rainfed area. International Journal of Agriculture and Biology, 7: 207-09.

Ali, A., Arshadullah, M., Ishtiaq, H.S. and Ali, M.I. (2012). Effect of different levels of sulphur on the productivity of wheat in a saline sodic soil. Soil Environment, 31(1): 91-95.

Arvind, V., Nepalia, V. and Kanthaliya, P.C. (2006). Effect of integrated nutrient supply on growth, yield and nutrient uptake by Maize (Zea-may L.) - wheat (Triticumaestivum L.) cropping system. Indian Journal of Agronomy, 51(1): 3-6.

Bajpai, R.K., Chitale, S.. Upadhyaya, S.K. and Urkurkar, J.S. (2006). Long -term studies on soil physico-chemical properties and productivity of rice -wheat system as influenced by integrated nutrient management in Inceptisol of Chhattisgarh. Journal of the Indian Society of Soil Science, 54(1): 24-29.

Benbi, D.K., Biswas, C.R., Bawa, S. and Kumar, S. (1998). Influence of FYM, inorganic fertilizers and weed control practices on some soil physical properties in a long experiment. Soil Use and Management, 14:
52-54.

Benbi, D.K. and Nieder, R. (2003). Handbook of Processes and Modeling in soil- Plant System. Haworth Press. NY, pp. 752.

Biswas, T.D. and Khosla, B.K. (1971). Building up of organic matter status of the soil and its relation to soil physical properties. Proceedings of the International Symposium on Soil Fertility Evaluation, New Delhi, pp. 831-42.

Chand, S., Anwar, M., and Patra, D.D. (2006). Influence of long-term application of organic and inorganic fertilizer to build up soil fertility and nutrient uptake in mint mustard cropping sequence. Communications in Soil Science and Plant Analysis, 37: 63-76.

Chondie, Y.G. (2015). Effect of integrated nutrient management on wheat: A review. Journal of Biology, Agriculture and Healthcare, 5(13): 68-76.

Choudhary, P.D., Jat, R.S. and Sharma, H.S. (2003). Integrated effect of Phosphorus, Sulphur and PSB inoculation on growth yield and nutrient uptake of wheat. Annals of Agricultural Research, 24(1): 12-16.

Dejene, K.M. and Mekonnen, L.S. (2012). Integrated Agronomic Crop Managements to Improve Tef Productivity Under Terminal Drought. In: Water Stress, Ismail Md. Mofizur Rahman and Hiroshi Hasegawa (Eds.). Retrieved from https://www.intechopen.com/books/waterstress/integrated-agronomic-cropmanagments-to-improve-tef-productivityunder-terminal-drought.

Desai, H.A., Dodia, I.N., Desai, C.K., Patel, M.D. and Patel, H.K. (2015). Integrated nutrient management in wheat (Triticum aestivum L.). Trends in Biosciences, 8(2): 472-75.

Devi, K.N., Singh, M.S., Singh, N.G. and Athokpam, H.S. (2011). Effect of integrated nutrient management on growth and yield of wheat (Triticum aestivum L.). Journal of Crop and Weed, 7(2): 23-27.

Gawai, P.P. and Pawar, V.S. (2006). Integrated nutrient management in sorghum (Sorghum bicolor)-chickpea (Cicer arietinum) cropping sequence under irrigated conditions. Indian Journal of Agronomy, 51(10): 17-20. 
Ghaffari, A., Ali, A., Tahir, M., Waseem, M., Ayub, M. (2011). Influence of Integrated Nutrients on Growth, Yield and Quality of Maize (Zea mays L.). American Journal of Plant Science, 63-69.

Haile, D., Nigussie-Dechassa, R, Abdo, W. and Girma, F. (2012). Seeding rate and genotype effects on agronomic performance and grain protein content of durum wheat (triticum turgidum 1. var. durum) in South Eastern Ethiopia. African Journals of Food, Agriculture, Nutrition and Development, 12(3): 6080- 6094.

Iqbal, A., Iqbal, M.A., Raza, A., Akbar, N., Abbas, R.N. and Khan, H.Z. (2014). Integrated nitrogen management studies in forage maize. American-Eurasian Journal Agricultural \& Environment Science. 14(8):744-47.

Jabbar, S.M.A., Begum, M.M., Cruz, P.C.S., Harun-ur-Rashid, M. (2008). Evaluation of different nutrient management practices for wheat-rice cropping system under agro ecological zone-1 in Bangladesh. Philippine Agric. Sci., 91: 269-77.

Joshi, E., Nepalia, V., Verma, A. and Singh, D. (2013). Effect of integrated nutrient management on growth, productivity and economics of maize (Zea mays). Indian Journal of Agronomy, 58(3): 434-36.

Joy, J.M.M., Ravinder, J., Rakesh, S., and Somashekar, G. (2018). A review article on integrated nutrient management in wheat crop. International Journal of Chemical Studies, 6(4): 697-700.

Kalhapure, A.H., Shete, B.T. and Dhonde, M.B. (2013). Integrated nutrient management in maize (Zea mays L.) for increasing production with sustainability. International Journal of Agriculture and Food Science Technology, 4(3): 195-206.

Kannan, R.L., Dhivya, M., Abinaya, D., Lekshmi, R.K. and Kumar, S.K. (2013). Effect of integrated nutrient management on soil fertility and productivity in maize. Bulletin of Environment, Pharmacology and Life Sciences, 2(8): 61-67.

Khadtare, S.V., Patel, M.V., Jadhav, J.D. and Mokashi, D.D. (2006). Effect of vermicompost on yield and economics of sweet corn. Journal of Soil and Crops,
16(2): 401-406.

Kumar, V., Punia, S.S., Lakshminarayan, K. and Narula, N. (1999). Effect of phosphate solubilizing analogue resistant mutants of Azotobacter chroococcum on sorghum. Indian Journal of Agricultural Sciences, 69: 198-200.

Louraduraj, A.C. (2006). Identification of optimum quantity of vermicompost for maize under different levels of fertilization. Journal of Ecobiology, 18: 23-27.

Mahapatra, P., Singh, R.P., Singh, B.P. and Sarkar, A.K. (2007). Long term effects of fertilizer, organic manure and amendments on soil health, crop productivity and sustainability. SSAC (BAU) Technical Bulletin, 4, 1-75.

Manna, M.C., Swarup, A., Wanjari, R.H., Ravankar, N.H., Mishra, B., Saha, M.N., Singh, Y.V., Shahi, D.K. and Swarup, P.A. (2005). Long term effect of fertilizer and manure application on soil organic carbon storage, soil quality, and yield sustainability under sub-humid and semi-arid tropical India. Field Crops Research, 93: 264- 80.

Maske, N.M., Pawar, S.B., Munde, G.R. and Patange, M.J. (2015). Integrated nutrient management and irrigation schedules on growth and yield of rabi maize. Bioinfolet, 12 (3): 622-23.

Meena, O., Khafi, H.R., Shekh, M.A., Mehta, A.C. and Davda, B.K. (2007). Effect of vermicompost and nitrogen on content, uptake and yield of rabi maize. Crop Research, 33(1-3): 53-54.

Mubarak, T. and Singh, K.N. (2011). Nutrient management and productivity of wheat (Triticum aestivum L.)- based cropping system in temperate zone. Indian Journal of Agronomy, 56(3): 176-81.

Nagavani, A.V. and Subbian, P. (2014). Productivity and economics of maize as influenced by integrated nutrient management. Current Biotica, 7(4): 283-93.

Pandey, I.B., Dwivedi, D.K. and Pandey, R.K. (2009). Integrated nutrient management for sustaining wheat (Triticum aestivum L.) production under late sown condition. Indian Journal of Agronomy, 54(3): 306309.

Pandey, K.K. and Awasthi, A. (2014). Integrated 
nutrient management in the maize (Zea mays L.) yield and soil properties. Internal Journal of Agricultural Sciences, 10(1): 244-246.

Parihar, C.M., Rana, K.S., Jat, S.L., Singh, A.K., Singh, D.K. and Pushpendra, K. (2010). Effect of land configuration and nutrient management on productivity, economics and energy requirement of pearlmillet Pennisetum glaucum)- mustad (Brassica juncea) cropping system. Ann. Agric. Res. New Series, 31(3\&4): 102-106.

Pawar, R.B. and Patil, C.V. (2007). Effect of vermicompost and fertilizer level on soil properties, yield and uptake of nutrients by maize. Journal of Maharashtra Agricultural University, 32(1): 11-14.

Rafique, E. and Rashid, A. (2006). Zinc deficiency in rain-fed wheat in Pakistan: magnitude, special variability, management and plant analysis diagnostic norms. Comm. in Soil Sci. and Plant Analysis, 37: 181-97.

Rao, K.S., Moorthy, B.T.S. and Pandalia, C.R. (1996). Efficient nitrogen management for sustained productivity in low land rice (Oryza sativa). Indian Journal of Agronomy, 41: 215-20.

Reddy, A.R., Singh, B. and Narwal, R.P. (2009). Effect of long term FYM and nitrogen application in bajra-wheat cropping system on yield and uptake of sulphur, iron and manganese by wheat crop. Annals of Biology, 25(2): 113-20.

Reena, Pandey, S.B., Tiwari, D.D., Nigam, R.C., Singh, A.K. and Kumar, S. (2017). Effect of integrated nutrient management on yield and nutrients uptake of wheat and soil health. International Archive of Applied Sciences and Technology, 8(3): 25-28.

Regar, P.L., Rao, S.S. and Vyas, S.P. (2005). Crop-residue management for increased wheat (Triticum aestivum) production under saline soils of arid fringes. Indian Journal of Agriculture Sciences, 75(2): 83-86.

Saad, O.A.O. and Hammad, A.M.M. (1998). Fertilizing wheat plants with rock phosphate combined with phosphate dissolving bacteria and V. Arnicorrhizaeas alternate for ca-superphosphate. Ann. Agric. Sci. Cairo., 43: 445-60.

Sangma, B., David, A.A. and Thoma, T. (2017).
Response of integrated nutrient on soil health (physico-chemical properties) and yield of wheat (Triticumaestivum L.). International Journal for Scientific Research \& Development, 5(3): 865-70.

Sarwar, G., Hussain, N., Schmeisky, H. and Muhammad, S. (2007). Use of compost an environment friendly technology for enhancing rice-wheat production in Pakistan. Pak J Bot., 39(5): 1553-58.

Sarwar, G., Hussain, N., Schmeisky, H. and Muhammad, S., Ibrahim, M. and Safdar, E. (2008). Improvement of soil physical and chemical properties with compost application in rice-wheat cropping system. Pak J Bot., 40: 275-282.

Sepat, R.N., Rai, R.K. and Dhar, S. (2010). Planting systems and integrated nutrient management for enhanced wheat (Triticum aestivum L.) productivity. Indian Journal of Agronomy, 55(2): 114-18.

Shilpashree, V.M., Chidanandappa, H.M., Jayaprakash, R. and Punitha, B.C. (2012). Influence of integrated nutrient management practices on productivity of maize crop. Indian Journal of Fundamental and Applied Life Sciences, 2(1): 45-50.

Shinde, S.A., Patange, M.J. and Dhage, S.J. (2014). Influence of irrigation schedules and integrated nutrient management on growth, yield and quality of rabi maize (Zea mays L.). International Journal of Current Microbiological Applied Sciences, 3(12): 828-32.

Shivakumar, B.G. and Ahlawat, I.P.S. (2008). Integrated nutrient management in soybean (Glycine max)-wheat (Triticum aestivum) cropping system. Indian Journal of Agronomy, 53(4): 273-78.

Sindhi, S.J., Thanki, J.D. and Desai, L.J. (2018). A review on integrated nutrient management (INM) approach for maize. Journal of Pharmacognosy and Phytochemistry, 7(4): 3266-69.

Singh, D. and Nepalia, V. (2009). Influence of integrated nutrient management on quality protein maize (Zea mays) productivity and soils of southern Rajasthan. Indian Journal of Agricultural Sciences, 79(12): 1020-22.

Singh, G. Sharma, G.L., Golada, S. and Choudhary, R. (2012). Effect of integrated 
nutrient management on quality protein maize (Zea mays L.). Crop Research, 44(12): 26-29.

Singh, G., Jalota, S.K. and Singh, Y. (2007). Manuring and residue management effects on physical properties of a soil under the rice wheat system in Punjab, India. Soil and Tillage Research, 94: 229-238.

Singh, R.V. and Kumar, R. (2010). Effect of organic and inorganic fertilizers on growth yield and quality and nutrients uptake of wheat under late sown condition. Progressive Agriculture, 10(2): 341-44.

Singh, R., Singh, B. and Patidar, M. (2008). Effect of preceding crops and nutrient management on productivity of wheat (Triticum aestivum L.) based cropping system in arid region. Indian Journal of Agronomy, 53(4): 267-72.

Singh, S.P., Aditya, S. and Choudhary, M. (2018). Response of integrated nutrient management on growth, yield and economics of Indian mustard (Brassica juncea L.) in Chhattisgarh plains. International Journal of Current Microbiology and Applied Sciences, 7(12): 135-140.

Singh, R. and Agrawal, S. K. (2005). Effect of levels of farm yard manure and nitrogen fertilizer on grain yield and use efficiency of nutrients on wheat (Triticum aestivum). Indian Journal of Agricultural Science. 75(7): 408-13.
Tejalben, P.G., Patel, K.C. and Vimal, P.N. (2017). Effect of integrated nutrient management on yield attributes and yield of wheat (Triticum aestivum L.). International Journal of Chemical Studies, 5(4): 1366-69.

Tetarwal, J.P., Ram, B. and Meena, D.S. (2011). Effect of integrated nutrient management on productivity, profitability, nutrient uptake and soil fertility in rainfed maize (Zea mays). Indian Journal of Agronomy, 56(4): 373-76.

Totawat, K.L., Jangir. R.K., Nagar, G.L. and Jat, S.L. (2001). Effect of flyash on the performance of wheat on Ustochrepts of sub - humid plains of India, 2001-2002.

Verma, N.K., Pandey, B.K. and Singh, U.P. (2012). Effect of sowing dates in relation to integrated nitrogen management on growth, yield and quality of rabi maize (Zea mays L.). Journal of Animals and Plant Sciences, 22(2): 324-29.

Wakene, N., Fite, G., Abdena, D. and Berhanu. D. (2007). Integrated Use of Organic and Inorganic Fertilizers for Maize Production. Utilization of diversity in land use systems: Sustainable and organic approaches to meet human needs. Tropentag, Witzenhausen, October 9 - 11 .

Yadav, D.S. and Kumar, A. (2009). Long-term effect of nutrient management on soil health and productivity of rice (Oryza sativa)- wheat (Triticum aestivum) system. Indian Journal of Agronomy, 54: 15-23.

\section{How to cite this article:}

Singh, S.P., Chanchala Rani Patel and Paikra, K.K. 2020. Integrated Nutrient Management: An Effective Approach for Sustainable Agriculture in Chhattisgarh: A Review. Int.J.Curr.Microbiol.App.Sci. 9(05): 1652-1662. doi: https://doi.org/10.20546/ijcmas.2020.905.186 